\title{
Different models for the Neolithisation of Albania
}

\author{
Adem Bunguri \\ Institute of Archaeology, Tirana, AL \\ bunguriar@gmail.com
}

\begin{abstract}
According to the archaeological evidence, the Neolithisation process in Albania seems to have passed through three different phases, with chronological gaps between them. The earliest phase is represented at the Vlusha site, where coarse monochrome pottery was found in the same layer as microlithic tools. The second phase can be traced back to the Konispol site, where Impresso pottery appeared immediately above the Mesolithic layer. The third phase is represented by the Podgorie I site, which is characterised by red monochrome slipped ware, white-painted pottery, polychrome pottery, as well as pottery with impresso and barbotine decoration.

IZVLEČEK - Arheološki podatki kažejo, da je proces neolitizacije v Albaniji potekal v treh različnih fazah z vmesnimi kronološkimi prekinitvami. Najzgodnejšo fazo predstavlja najdišče Vlusha, kjer je bila odkrita groba enobarvna (monokromna) lončenina $v$ isti plasti kot mikrolitska orodja. Drugo fazo smo prepoznali na najdišču Konispol, kjer se lončenina, okrašena v stilu Impresso, pojavlja tik nad mezolitsko plastjo. Tretjo fazo predstavlja najdišče Podgorie I, za katerega je značilna rdeče premazana enobarvna (monokromna) lončenina, belo slikana lončenina, večbarvna (polikromna) lončenina, kakor tudi lončenina, okrašena z vbodi in barbotinom.
\end{abstract}

KEY WORDS - Albania; Neolithisation; pottery; interpretative model

\section{Introduction}

Positioned at an intersection of the network of land routes that connect Anatolia, the Balkans and the Western Mediterranean, Albania is a highly favourable location, which determined the cultural features of its Neolithic civilisation (Fig. 1). The Neolithisation process is complex, involving successive socialhistorical events and interactions which happened in a definite space and time, conditioned by numerous circumstances and geographical and bio-economical conditions in particular (Budja 1999.121). The debate about the Neolithisation process has been a long one, and includes various hypotheses, from the indigenous to the migratory models (Budja 1993. 179-193; Zvelebil 1995.107; Özdoğan 1995.25; Bánffy 2005.75). Earlier models of Neolithisation based on a single wave of colonisation and a single scenario have recently been supplanted by more complex models involving interaction and reciprocal cultural impacts (Oross, Banffy 2009.175). The
Early Neolithic culture in Albania combines elements of the Anatolian-Balkan and Adriatic-Mediterranean cultural complexes of this period. As such, the territory of Albania is an important case study area for defining the spatial extent of the Mediterranean and Continental cultural groups that were present in this region during the Neolithic period. We find various regional cultures in Albania that have attracted the attention of prehistoric archaeologists in recent decades who suggested different models, ranging from the indigenous to diffusionist theory.

Our knowledge about the very beginnings of the Early Neolithic is very limited; one or two sites can be ascribed to this period: Vlusha in the south-central part of Albania, and Konispol on the southwest coast. A vertical sequential stratigraphy has been found only in the Konispol Cave, while at the open site at Vlusha there is only horizontal stratigraphy present. 
On the other hand, the Podgorie site has yielded quite good stratigraphical and archaeological evidence to confirm a late stage of the Early Neolithic which resulted from migration. However, according to the archaeological evidence, Albania can be divided longitudinally between two main cultural Early Neolithic complexes, as shown in the following map (Fig. 2).

The archaeology of the Early Neolithic in Albania shows that the culture of this period developed in three chronological phases, even with hiatuses between them, each corresponding to the three different models of the Neolithisation process (Fig. 3).

\section{Model no. 1: Vlusha I-II}

Vlusha is a site where Mesolithic and Early Neolithic deposits were found in two different areas of the site, Vidhëz (point A) and Armenina (point B), approx. 300m apart. The site lies on a mountain slope $800 \mathrm{~m}$ above sea level, on the right bank of the Kapinova River, near the eponymous village in the district of Skrapar (Fig. 4).

The site has been known since 1972, when Luftin Ylli collected several objects discovered by chance at this location which are reminiscent of the Mesolithic tradition of tool production (Prendi 1982.190; 1990.300, Pl. I, 1-8). A year later, a small trial excavation was carried out by Muzafer Korkuti, who concluded that the finds dated to a transitional period between the Mesolithic and Neolithic. The last trial excavation at Vlusha, carried out by Ylli in 1990, revealed different stratigraphic sequences and cultures, each indicating two successive periods of development, termed Vlusha I and Vlusha II, and related to the Late Mesolithic and Early Neolithic, respectively.

\section{Vlusha I}

The first trench of $3 \times 3 \mathrm{~m}$ was excavated at Vlusha I (Vidhëz), which revealed a cultural deposit reaching a depth of $0.85 \mathrm{~m}$ that comprised two separate cultural horizons, as can be seen in its eastern profile (Fig. 5):

(1) The lower horizon, $0.50 \mathrm{~m}$ thick, consisted of dark brown soil, with late Mesolithic flint silex and no pottery.
(2) The upper horizon, $0.30-0.35 \mathrm{~m}$ thick, consisted of light brown soil that contained flint silex and no pottery. The cultural layer dates to the late Mesolithic period, perhaps the Tardenoisien phase (Prendi 1990.300).

The flint tools are of the same type as those found on the surface; the same flint tools, mainly in grey and whitish colours, with very small dimensions $(1.5-2 \mathrm{~cm})$ and irregular trapezoidal shapes, which are typical examples of Mesolithic microlithic tools, are apparently in the Tardenoisien tradition. Based on the microlithic character of the silex (Pl. 1.1-8) and the absence of ceramics, the possibility that a Mesolithic settlement existed at Vidhës was considered. However, the suggestion remains open to debate, as the finds were insufficient and not all typologically definable. The excavations at Vlusha revealed that there were two distinct cultural horizons, of which the layer at point A (Vidhëz-Vlusha I) had no pottery, but is securely dated to an earlier period, i.e. the Mesolithic, while the layer at point B (ArmeninaVlusha II) dates to an early phase of the Neolithic. However, this aspect requires further investigation, as Vlusha is indeed a site with great potential for studying the process of Neolithisation of this area, given that the earliest Neolithic layer here, Vlusha II, follows directly after the Mesolithic layer, Vlusha I.

\section{Vlusha II}

The second trench of $3 \times 3 \mathrm{~m}$ was excavated in 1990 at point B (Armenina). Vlusha II is of particular in-

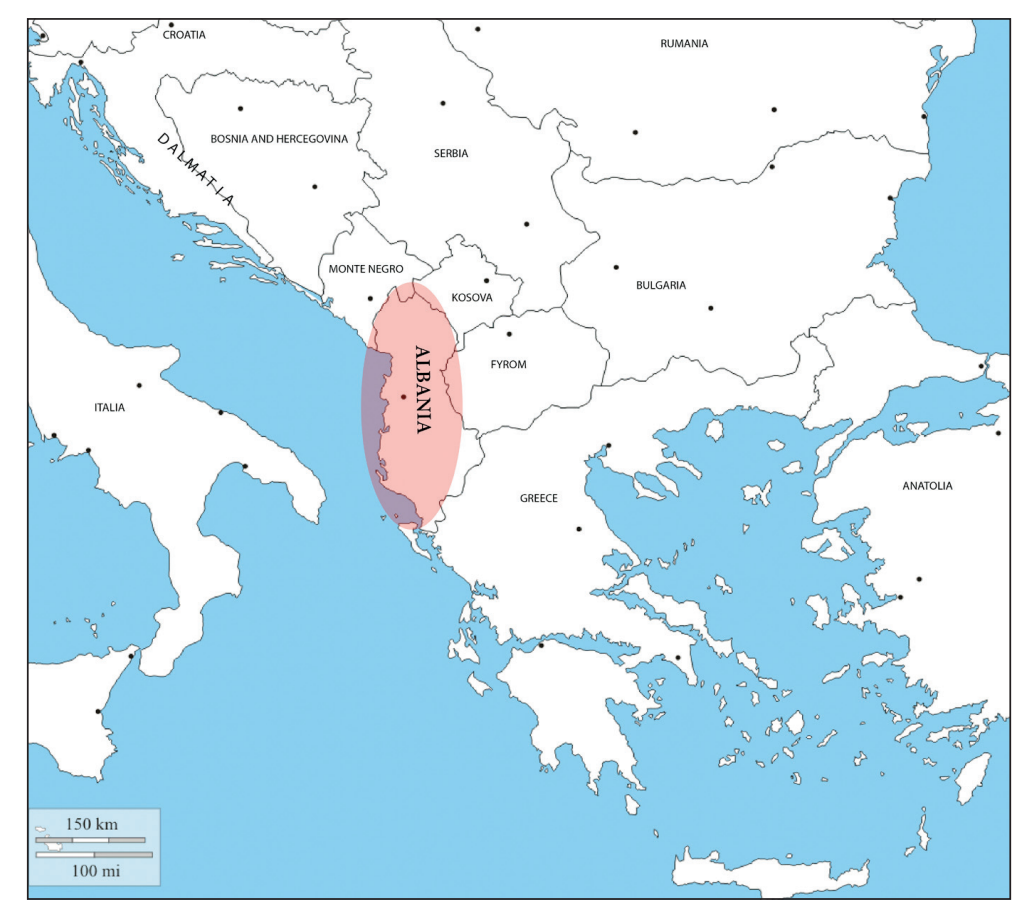

Fig. 1. Map of the Balkans and Albania. 


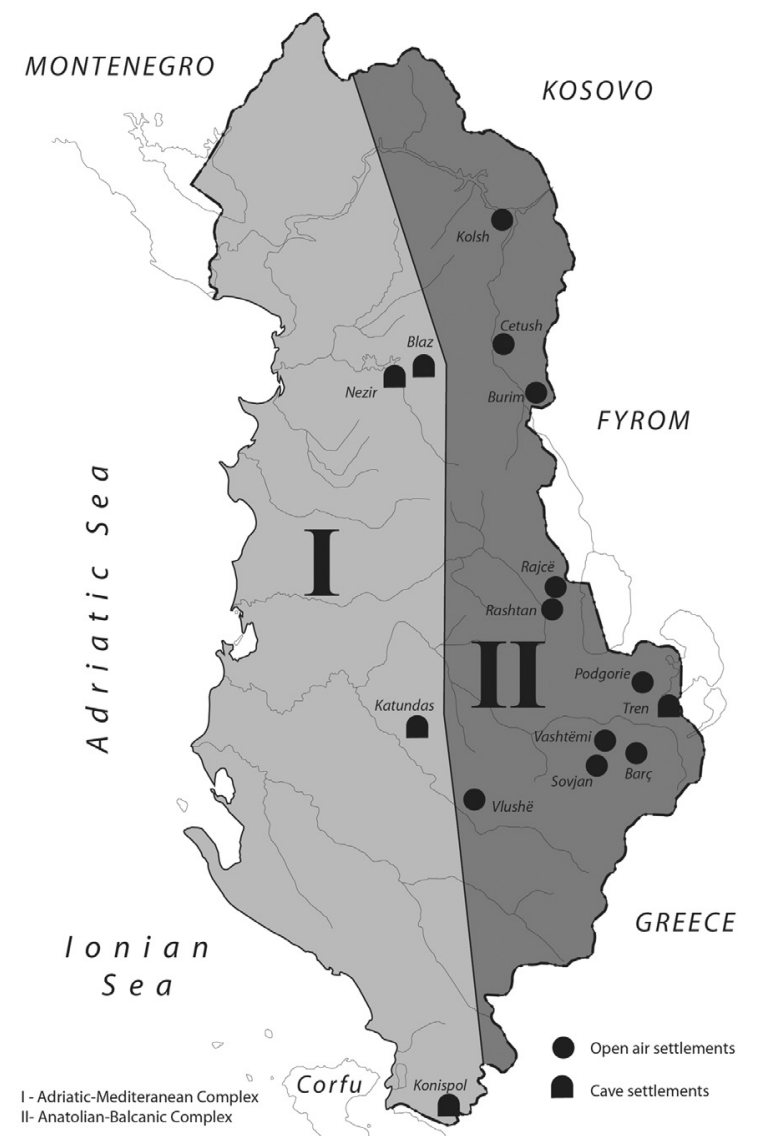

Fig. 2. Map of Early Neolithic cultural complexes in Albania.

terest because of its monochrome pottery and strong Mesolithic tradition. The Early Neolithic deposit discovered at point B (Armenina), which includes monochrome dark grey pottery sherds, has been associated with Mesolithic microlithic flints. The cultural layer was $0.80 \mathrm{~m}$ thick and clearly divided by two building levels with traces of burned earth and hearths, as can be seen in its eastern profile (Fig. 6):

(1) The first and the earliest horizon is a layer $0.20 \mathrm{~m}$ thick, light grey layer lying directly over the natural bedrock and consisting of clay and sand, and culturally sterile.

(2) Traces of a fireplace and the remains of a hearth, measuring $0.15-0.30 \mathrm{~m}$.

(3) The second occupation horizon consists of two layers. The first layer is $2.20 \mathrm{~m}$ thick and begins with traces of a hearth. It was made of compact dark brown clay which contains microliths and a few pottery.
(4) The second layer, measuring $0.40 \mathrm{~m}$ in thickness, consists of light brown clay and a few pottery sherds and flint tools. The layer appears homogenous, containing only pottery, small flint chips, nuclei and a few objects that show traces of use.

The material culture of both occupation horizons at Armenina (Vlusha II) is represented by some flint tools of micro-dimensional silexes (Pl. 2.1-20) and monochrome ware produced with modest technology, highly fragile and poorly fired. It has a dark grey sandy clay fabric, and in a few cases reddish or ochre colouring. Coarse ware of fabric with medium-sized grains predominates, while pottery with a coarser grained fabric is less frequent. The pottery is highly fragmented and contains few diagnostic elements. Spherical and semi-spherical cups predominate, along with conical bowls, generally with a flat base, which in a few cases appear to have small tubular handles, particularly in the case of the coarser fabric ware.

Decoration is rarely present and consists of impressed lines placed around the neck or just below it, mainly observed on the coarser fabric ware (Pl. 3.1114). Impresso and barbotine style decorations are entirely absent. The excavated area in this sector, except for a few flint tools, produced no tools of polished stone or bone. Bones are generally absent, except for a single jaw fragment with three pre-molar teeth of a large unidentified wild animal, which were
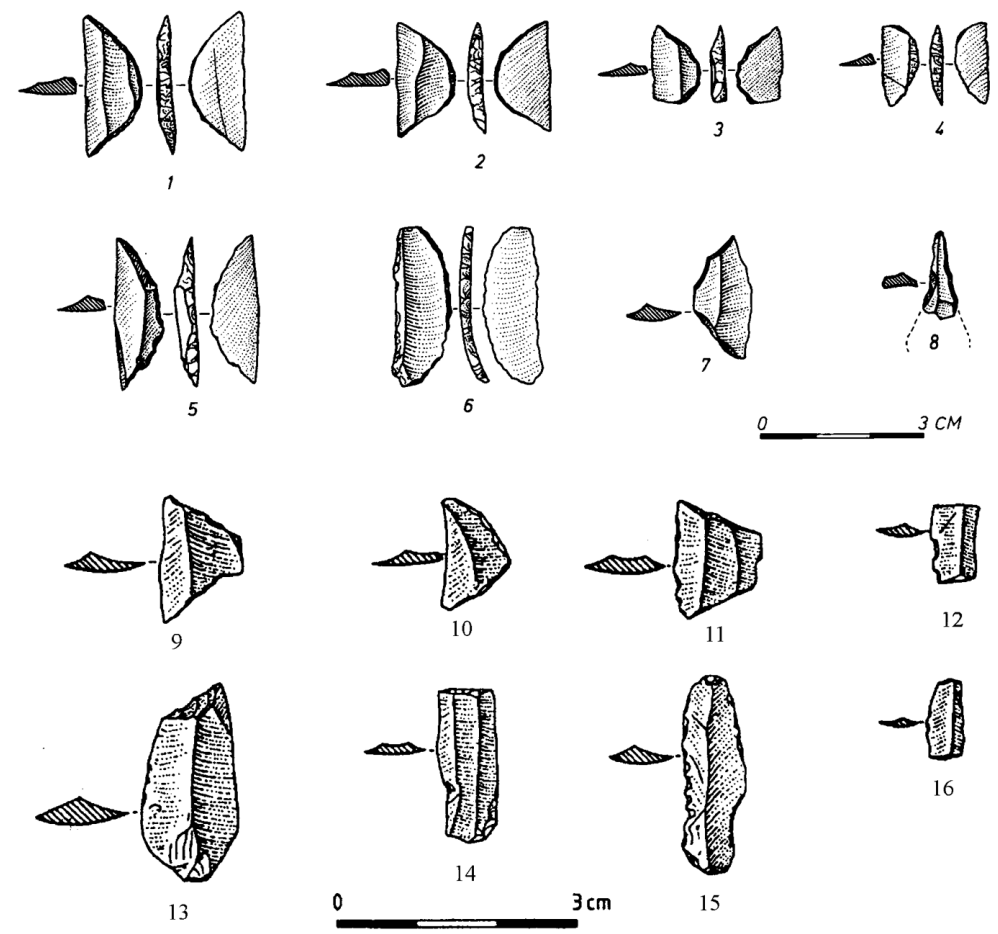

Pl. 1. Flint tools. 1-8: Vlusha I; 9-16: Konispol II. 
found at $0.70 \mathrm{~m}$ depth, in the upper section of the first occupation level.

The material culture is particularly striking because of the presence of micro-dimensional silexes, some of which are similar in shape and retouch style to Mesolithic microliths found during the excavations at Vidhëz (Vlusha I; Prendi 1990.300). Of particular chronological and cultural relevance among these finds are the microliths, especially one example of elongated shape with fine retouch on the back, identical in form and production style to microliths that have been previously found here. The general characteristics of the pottery at Vlusha do not correspond to any of the Neolithic cultures known so far in Albania, which makes the cultural and chronological evaluation of this material complex, especially as the material is limited in quantity and has no clear stratigraphic provenance. However, the monochrome pottery, its poor firing quality, the simplicity of the shapes, and the limited and uniform decoration indicate that this material represents a new cultural phenomenon that cannot be chronologically associated with a classic phase of the Early Neolithic period. In this sense, it is interesting that in the layer that contained pottery finds, some microliths are similar to those found at site B (Vidhëz). Thus, we believe that the locality of Vlusha was occupied during both the Mesolithic and Early Neolithic.

It is worth pointing out that Vlusha differs from the above-mentioned settlements in that the elements of the Mesolithic tradition appear in its early phase in association with monochrome ware and not with Adriatic Impresso ware. This phenomenon has been stratigraphically documented at the Sidar settlement on Corfu, where the layer with monochrome Early Neolithic pottery and many (non-microlithic) flint tools, at a depth of $0.50-0.60 \mathrm{~m}$ (Sidar C, Base), was located over a Mesolithic layer (Sidar D) and covered by an alluvial hiatus of $0.70-0.80 \mathrm{~m}$ in depth (Sidar C, Middle), followed by a layer of Adriatic Impresso ware accompanied by many flint tools at 0.15m depth (Sidar C, Top; Sordinas 1969.402-407, Pl. III; 2003.89). The same stratigraphic sequence was observed at Škarin Samograd in Central Dalmatia, where a horizon of monochrome ware (Samograd I) is followed by a layer of Adriatic Impresso ware (Müller 1991.311-358; 1988.232-234). Accord-

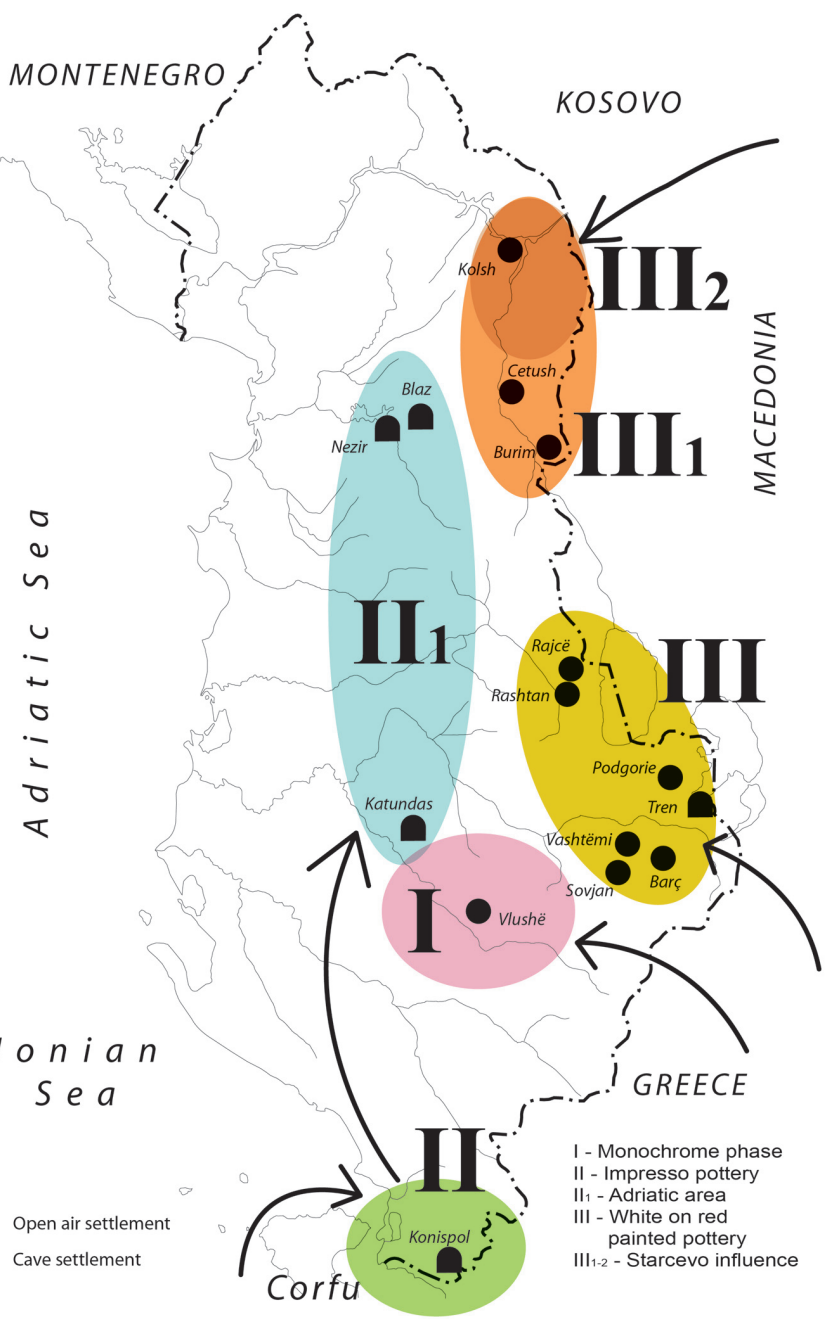

g. 3. Map of three phases of Neolithisation in Albania.

ing to the radiocarbon dates, the monochrome pottery from Sidari C Base dates to about 6610-6420 calBC (Müller 1991.355) and about 6825-6241 calBC (Briam, Heyed 2001.200-202). The impresso pottery of Sidar C Top layer is dated to 6410-5990 calBC (Sordinas 1968.26; Müller 1991.356) or 6569-5850 calBC (Briam, Heyed 2001.200-202), with a gap of almost 300 years. At Škarin Samograd, the horizon with monochrome pottery (Samograd I), is dated to $5660-5560$ calBC, and followed by a layer with Adriatic type B Impresso pottery (Samograd II), which is dated to 5630-5470 calBC (Müller 1988.219-224; 1991.354-355), with a gap of 150 years.

The coarse dark grey monochrome pottery at Vlusha IIa, both in forms and decoration, is similar to the monochrome pottery from the Krainici settlement in the Struma valley in Southwest Bulgaria. The decoration on the pottery from both settlements consists only of plastic ornamentation (Stefanova 1996. 16-17). In the later one, the earliest building level 

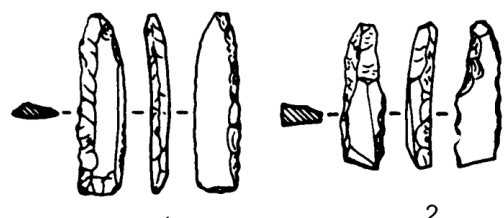

2

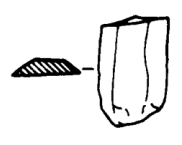

3
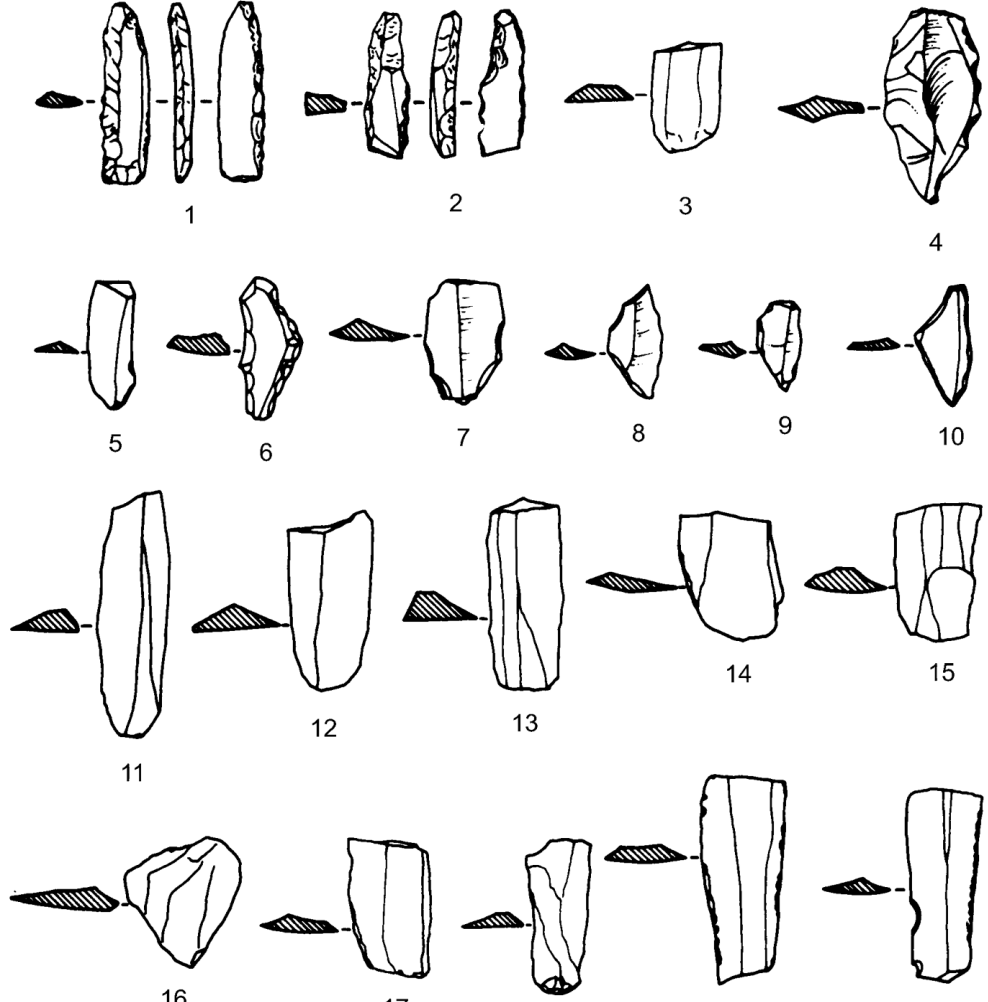

16
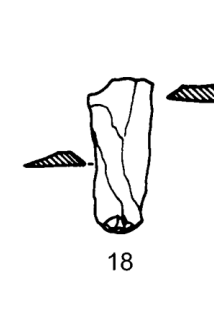

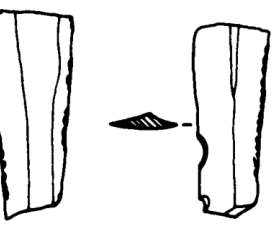

19 $3 \mathrm{CM}$

Frühkeramikum) (Milojčić 1959.5,

$P l .5$ ), with pottery from Krainici in the Struma valley or even with the monochrome pottery from the first building level at Koprivec, Poljanica Plateau, and Pomoshtica in Southwest and Northeast Bulgaria (Stefanova 1996.16-18, Pl. I-IX). The monochrome pottery at Kuprivec has been dated ${ }^{14} \mathrm{C}$ to $c$. 6300-6200 calBC (Schubert 2005.242, Fig. 2) and at Poljanica plato to $c .6200$ calBC (Schubert 2005.242, Fig. 2) or between $6180-6120$ calBC (Nikolova 1998.128; Budja 2001.36). However, the closest analogies to the dark grey coloured monochrome pottery of Vlusha IIa were found at the settlement of Krainici in the Struma valley in Southwest Bulgaria (Stefanova 1996.16-17, Pl. I.1-4; Todorova 2003.264).

Similar dark brown monochrome pottery with quite simple forms was found in the oldest Haçilar IX layer as well as at Çukuruçi Höyük in

\section{Pl. 2. Flint tools from Vlusha IIa.}

with monochrome pottery was covered after a hiatus by two other Early Neolithic building levels, in which white-on-red painted pottery appeared. (Stefanova 1996.16-17, Pl. I.1-4). A similar situation was observed at the Koprivec settlement in Northeast Bulgaria, where the Early Neolithic layer was formed by two building levels which followed each other without interruption. The earliest building level contained similar monochrome pottery, and its second building level, besides the monochrome, contained some fragments of white-on-red painted pottery (Stefanova 1996. 17). Similar cases were reported at the oldest Early Neolithic building level at Pomoshtica and Poljanica plato in Northeast Bulgaria, which were covered by a second building level where some white-on-red painted pottery was found (Stefanova 1996.17-19). The monochrome pottery at Koprivec was ${ }^{14} \mathrm{C}$ dated to $c .6300-6200 \mathrm{calBC}$ (Schubert 2005.242, Fig. 2) and at Poljanica plato to about 6200 calBC (Schubert 2005.242) or c. 61806120 calBC (Nikolova 1998.128; Budja 2001.36).

The monochrome pottery and the simple shapes found at Vlusha indicate a possible affinity with the early monochrome ware of Sidar and Škarin Samograd, despite a few local differences, as well as with the early monochrome pottery from Thessaly (ger.
Aegean Anatolia, and most recently at the oldest building levels at Barçin Höyük VIe and VId in Northwestern Anatolia, ${ }^{14} \mathrm{C}$ dated to between 6620-6570 calBC and 6500-6400 calBC, which precedes the oldest building level at Fikir Tepe (Gerritsen et al. 2013.60-62). These data show that simple monochrome pottery is the earliset in the Anatolian-Balkan complex of the Early Neolithic, followed in the Eastern Balkans by a white-on-red painted pottery layer (Todorova 2003.264; Krauß 2011.110). This chronological priority of monochrome pottery has also been confirmed in the Adriatic-Mediterranean

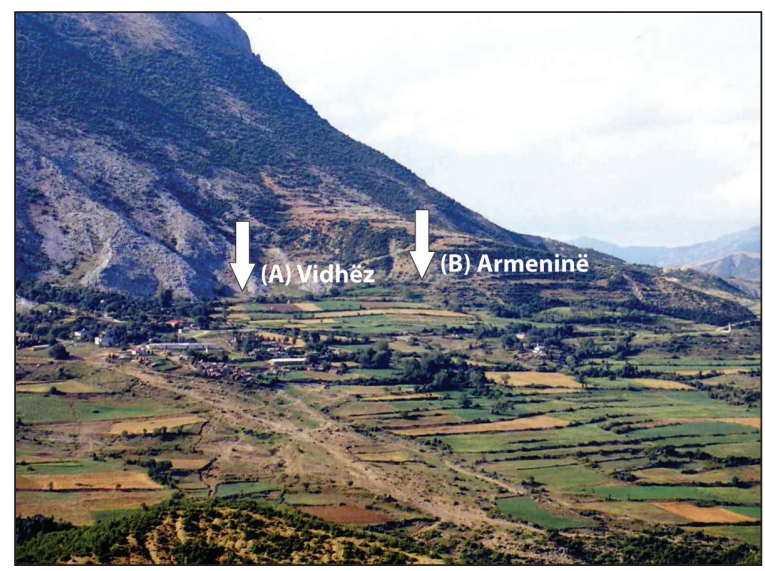

Fig. 4. View of Vlusha. 
complex of the Early Neolithic, where the monochrome pottery layer was followed after a hiatus by an Impresso layer (Müller 1988.219-220; 1991.354).

These similarities provide indications of the cultural and chronological affiliation of Vlusha with the wider Aegean-Balkan region, as well as connecting the Neolithisation process of this area to that of the Aegean regions. The simple monochrome pottery at Vlusha IIa, weakly fired and dark grey in colour, as well as the lack of Impresso pottery, suggest that Vlusha IIa preceded the Konispol IIIa layer which yielded Impresso pottery. In this context, Vlusha IIa seems to be parallel with Sidar C Base (Corfu) and Škarin Samograd I (Central Dalmatia). Based on this chronological priority of Vlusha IIa preceding the other Early Neolithic cultures in Albania, as well as its analogies with contemporaneous Balkan cultures (Todorova 2003.264), we believe that this culture, originating in Anatolia, may be considered a representative of the earliest Neolithic that arrived in Albania.

However, since excavations at this site remain limited, future investigations are required to fully clarify the picture. The strong Mesolithic tradition supports the idea that pre-Neolithic groups were involved in the Neolithisation of the region. On the other hand, the presence of coarse monochrome pottery, known from some other Early Neolithic sites in the Southern Balkans, seems to indicate that the first farmers arrived in this part of Albania through the first wave of Neolithisation, known as 'Monochrome' Neolithic. It appears that two different populations lived together at this settlement, the indigenous groups and the newcomers, undergoing processes of assimilation and integration. According to the archaeological evidence, we believe that small migratory groups were involved, having arrived from one or various directions and for seasonal habitation. The newcomers seem to have arrived at Vlusha along the Anatolian-Balkan route, mainly through the settlement of Krainici in the Struma valley, where the monochrome pottery is more similar. In conclusion, I believe that Vlusha IIa represents the 'leap-frog colonisation' model, following Marek Zvelebil's classification (Zvelebil 2001.2).

\section{Model no. 2: Konsipol IIIa}

The second model can be traced back to the site at Konispol (Saranda district), in Southwest Albania, where Early Neolithic Impresso pottery appears immediately above the Mesolithic layer. The Konispol cave is located in the southern extreme of Albania in

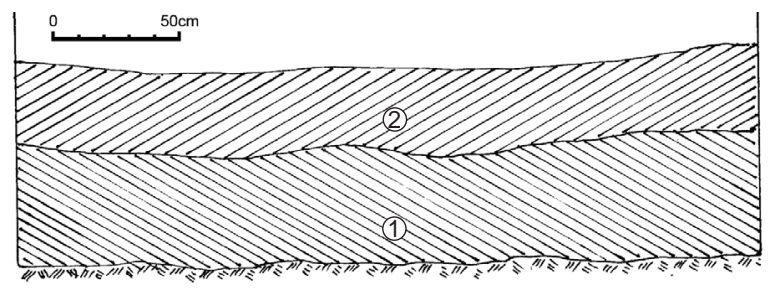

Fig. 5. Vlusha I profile.

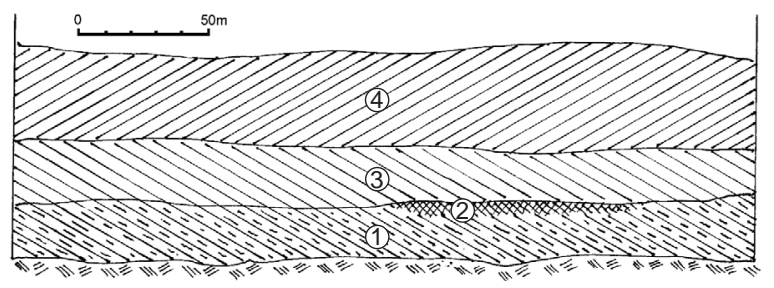

Fig. 6. Vlusha II profile.

the lime formation of the Saraçin Mountains, $400 \mathrm{~m}$ above sea level, near the Ionian Sea (Fig. 7).

It was uncovered thanks to systematic excavations carried out by a joint Albanian-American team (199294). According to the relative chronology established by the excavators, the cave provides the best example of a clear stratigraphic sequence from the Upper Paleolithic (Konspol I), Mesolithic (Konispol II), Early Neolithic (Konispol IIIa), Middle Neolithic (Konispol IIIb), Late Neolithic (Konispol IIIc), Eneolithic (Konispol IV), Early Bronze Age (Konispol V), Iron Age (Konispol VI), and Archaic and Hellenistic periods (Konspol VII) (Korkuti et al. 1996.183-202) (Fig. 8).

\section{Konispol II}

The Konispol cave is the settlement where the first compact layer of Mesolithic culture in Albania was discovered, lying immediately above an Upper Palaeolithic layer. That the layer was Mesolithic was demonstrated by the date of each of the two levels within it to the period between $7630 \pm 140$, calibrated as 7000-6100 calBC (Forenbaher, Miracle 2006. 93, Pl.2) and 7510 \pm 90 (Korkuti et al. 1996.197), calibrated as 6510-6100 calBC (Forenbaher, Miracle 2006.93, Tab. 2). The Mesolithic tools are of highquality flint, predominantly red and brown, and with fine, high-quality retouch (Korkuti et al. 1996.185, 197, 200). They comprise of small geometric microlithic tools, mainly triangular or trapezoidal scrapers with a fine single blade or terminal retouch, or dogtooth blades with a fine single or bifacial retouch (Pl. 1.9-16). The lithic industry was accompanied by faunal finds, including wild goat (Capra ibex) (Korku$t i$ et al. 1996.185, 200). With regard to the technical and morphological aspects, the microlithic finds at Konispol II are similar to those at Vlusha (Korkuti 


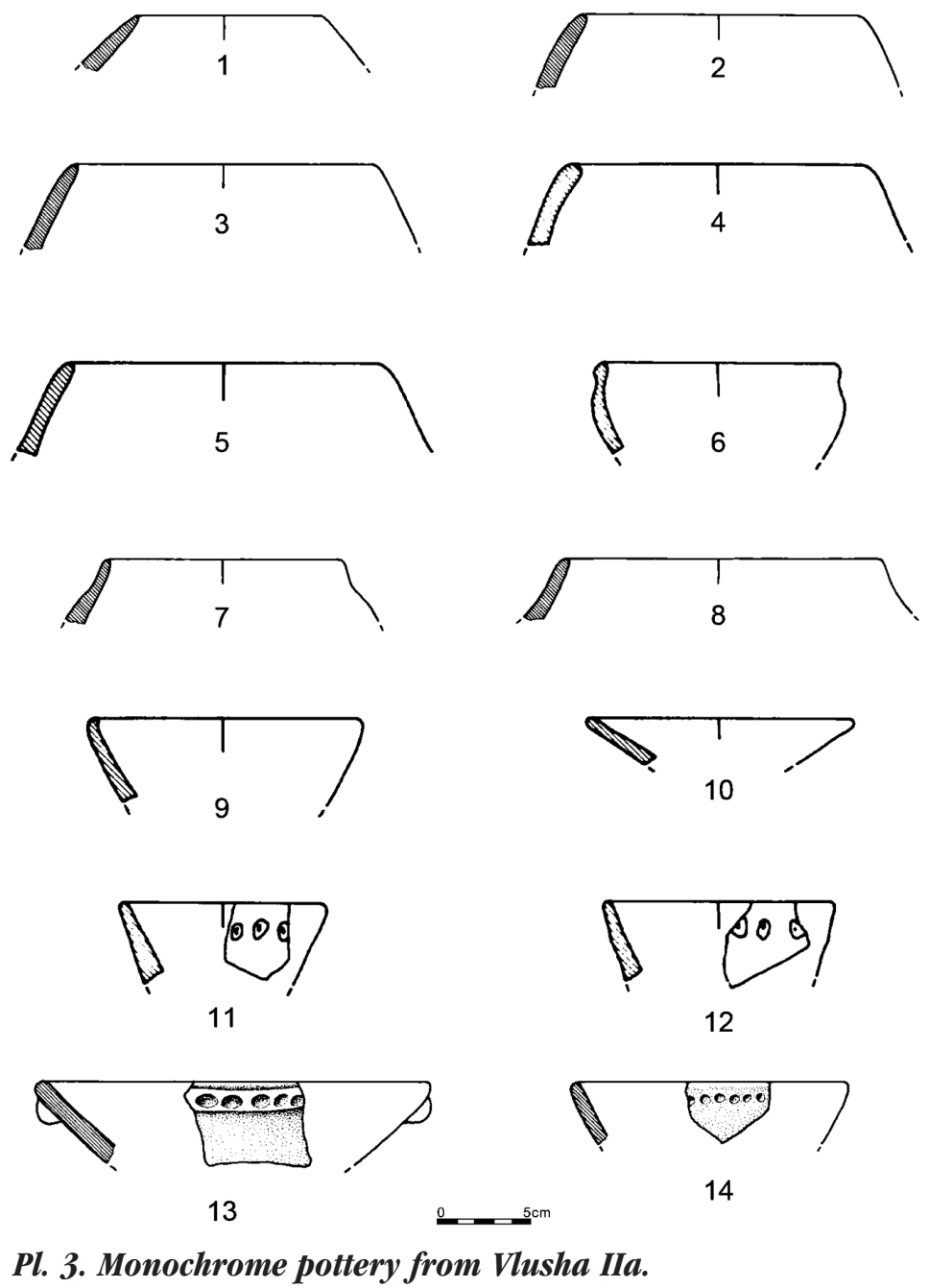

can be found between Konsipol II and Mesolithic Sidar on Corfu, despite the fact that the small lithic tools at the latter were produced in a slightly less elaborate manner (Sordinas 1969.Fig. б).

\section{Konispol IIIa}

Most of the stratigraphic data were obtained from trench VIII, where the cultural deposit reached $4.20 \mathrm{~m}$. The Neolithic layer, Konispol III, consists of three successive occupation levels, namely Konispol IIIa-c, which correspond to the Early, Middle and Late Neolithic phases, respectively. The Early Neolithic layer, Konispol IIIa, ${ }^{14} \mathrm{C}$ dated to 6170-5800 calBC (Korkuti et al. 1996. 197), and follows immediately after the Mesolithic layer, Konispol II (65106100 calBC). This stratigraphic sequence is of particular interest for the interdisciplinary study of the Neolithisation process in the south-western region of Albania. According to the excavators, the Early Neolithic phase at Konispol is represented by pottery that, although of limited quantity, is significant in determining the chronological and cultural character of the deposit in which it was found. It is mostly of coarser fabric, made of a mixture of clay and fine sand and very well fired (Korkuti et al. 1996.198, Pl. I). Light slip appears to have been applied to some of the dishes, while others have a smoothed surface. Red and reddish brown are the predominant colours, while dark grey is also observed in a few cases. Depending on the intensity of firing, the background colour of some fragments appears to have double nuances. Typologically, the Early Neolithic pottery at Konispol was not very varied. The most common types of vessels are cups with a straight or slightly inward curved rim, a rare type of cup with a conical trunk, and dishes with a body which gradually narrows towards the neck (Korkuti et al. 1996.198, Pl. I). The Konispol IIIa vessels mostly do not have handles (Pl. 4.1-12).

The Impresso pottery connects layer Konispol IIIa with the much wider area of the Early Neolithic Adriatic complex.

Fig. 7. View of Konispol Cave. 
The ceramic assemblage at Konispol IIIa has parallels with that of Level C Top at Sidar (Corfu), ${ }^{14} \mathrm{C}$ dated to $6410-5990$ calBC (Müller 1991.356) or 6390-6020 calBC and 6550-5800 calBC (Forenbaher, Miracle 2006.95, Pl. 3) and with the Impresso ware from Koirospilios (Leukas) (Dörpfeld 1927.Tab. 836), as well as with other sites on the Italian side of the Adriatic coast. The discovery of a large number of domesticated animal bones in the Early Neolithic layer at Konispol, mainly of goat and sheep, and a small quantity of carbonised grain seeds (Korkuti et al. 1996.201) attest to the emergence of an early form of agricultural and pastoral economy in this area at the time. A complete study of the floral and faunal data recovered from the site, however, is a prerequisite for any closer examination of the question of the Neolithisation of south-western Albania.

Konispol fits the model of an autochthonous culture, and has yielded data on the transformation of its Mesolithic huntergatherers into Neolithic herders, mainly of sheep and goat. We think that the Ko-
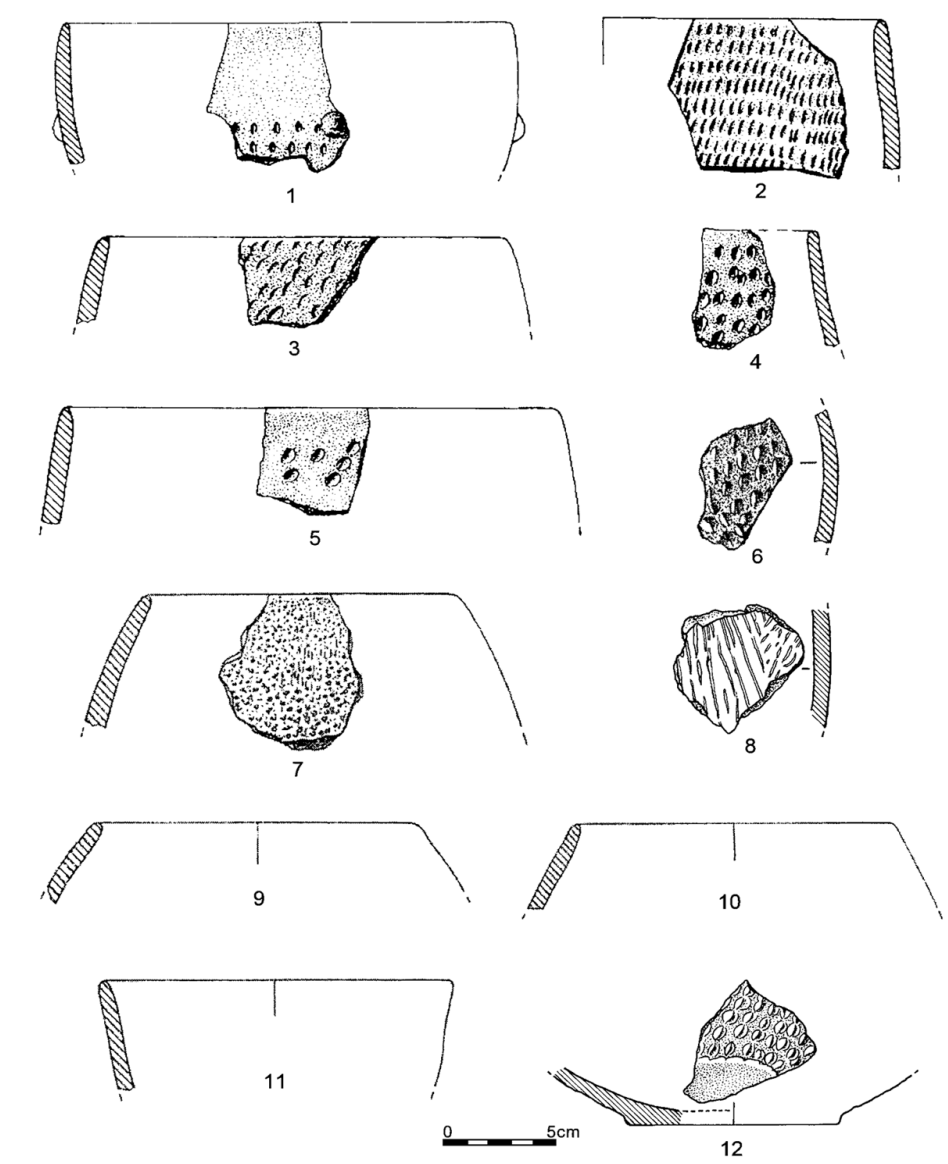

Pl. 4. Impresso pottery from Konispol III. where food production preceded pottery production, a known scenario in Greece (e.g., Francthi cave, Argissa Magula, Nea Nikomedia) and the Eastern Adriatic (e.g., Crvena Stijena, Icoana; Budja 1993.179, 181).

We believe that the Impresso pottery came to Konispol by way of contacts and exchange between local herders and farmers. We believe this because of the huge prior chronological data from Sidar C Top at 6410-5990 calBC (Korkuti et al. 1996.197; Korkuti 2003.221), or later as 6390-6020 calBC and 65505800 calBC (Forenbaher, Miracle 2006.95, Pl. 3), compared with the Konispol layer with impresso pottery dated to 6170-5800 calBC (Korkuti et al. 1996. 197; Korkuti 2003.221) or 6000-5550 calBC (Forenbaher, Miracle 2006.95, Pl. 3). The Konsipol cave fits the so-called 'regional contact model' involving trade and the exchange of ideas (Zvelebil 2001.2), as well as individual frontier mobility, according to Zvelebil's classification.

\section{Model no. 3: Podgorie I-Vashtëmi}

This cultural group is found mainly in South-eastern Albania, with its centre in the Korça basin, where

the main sites at Podgorie, Vashtëmia and Barçi were discovered. Frano Prendi named the group, based on the two most important sites, after his excavation at Podgorie in 1982.

At the three settlements, the Early Neolithic cultural deposits lay directly above the sterile levels of the plain, and were not preceded by any other older cultural layer to which the Podgorie I-Vashtëmi cultural group could be related.

Podgorie has yielded the richest data and shows the clearest development of this Early Neolithic group. On the basis of trial excavations, it has been suggested that the occupied part of the site extended over approx. $2500 \mathrm{~m}^{2}$. Aside from Early Neolithic deposits, late material of the Middle Neolithic, Eneolithic, Early and Late Bronze Age was also found.

The cultural layer consists of seven building levels (3.10-3.20m in depth), developed over three phases, Ia-c (Fig. 9). The two earliest phases, Podgorie Ia-b, represent the classic stages in the development of this culture, while phase Ic is a stage of decline. The main difference between Podgorie Ia and Podgorie Ib is that barbotine decoration appears only in 


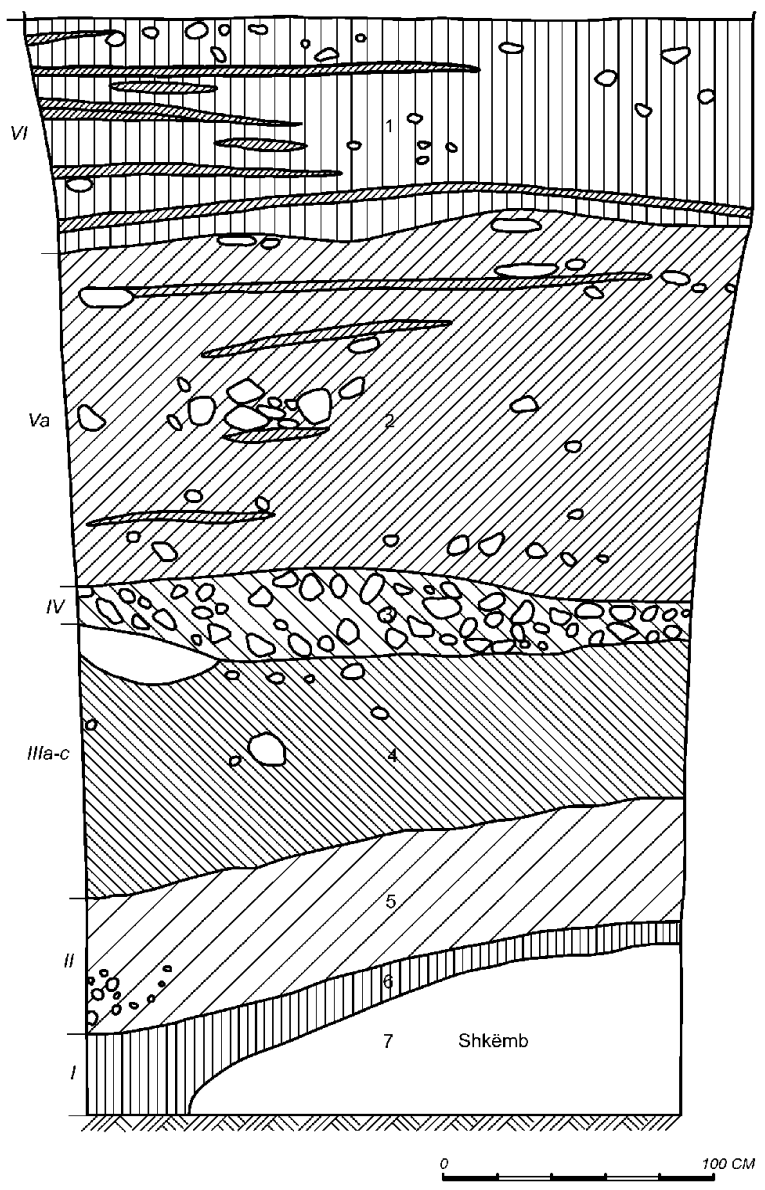

Fig. 8. Konispol profile.

phase $\mathrm{Ib}$, a phenomenon that has also been observed in the neighbouring site's respective layers at Vashtëmi in the Korça basin.

\section{Podgorie Ia phase}

The earliest phase, Podgorie Ia, corresponds stratigraphically to horizons I-IV of the cultural deposit. The ceramic groups of this phase are fine monochrome red slipped ware, monochrome dark grey or brownish slipped ware and painted ware (Pls. 5-7). Painted pottery is the main characteristic of this phase, which appears in the following styles and motifs:

- white-on-red slipped ware, and in fewer cases, grey-to-black, in a style similar to A3a of the preSeklo phase (Wace, Thompson 1912.59);

- white-on-red or cream slipped ware, in a style similar to A3 $\beta$ of Neolithic Thessaly (pre-Sesklo phase) (Wace, Thompson 1912.59) (Tabs. 5.1-10; 6.1-13);

- polychrome pottery in three colours, mainly white and cream on red slipped ware, in a style similar to B3 $\beta$ of phase Ib of Neolithic Thessaly or the proto-Sesklo phase (Wace, Thompson 1912.59, Pl. VII, 1-16);
- brown on red slipped ware, with straight or sinuous linear motifs, and sometimes combined with white motifs on a red ground;

- pottery with the entire surface painted white, and dark grey pottery.

The Podgorie Ib phase includes the same pottery categories as Podgorie Ia, as follows: white on red painted ware is also present, but in not in the same quantities as in the earlier phase; Impresso pottery increases in frequency compared to the preceding phase; incised ornaments appear very rarely; nail pinching and nail printing techniques can be identified; shallow grooved lines are rare. Red slipped monochrome ware gradually begins to decrease until it almost disappears completely in the following phase Ic. A new phenomenon that is exclusively related to this phase and distinguishes it as a separate stage in the classic development of this culture is the appearance of barbotine decoration.

The Podgorie Ic phase refers to the last occupation horizon. The main pottery categories in this phase are: autochrome reddish pottery with brownish and dark grey surfaces; matte red monochrome pottery; Impresso and barbotine pottery; red slipped ware is very rare, while matte white-on-red painted pottery disappears, as well as painted ware and red slipped monochrome ware. The Podgorie Ic phase represents the final stage of development of the Early Neolithic culture of Podgorie I.

Podgorie Ia-b has analogies with Anzabegovo-Vršnik Ic based on the white-on-red painted pottery with advanced ornamental features, as well as Impresso style pottery and several typical pottery shapes, especially vessels with three legs. It has analogies with Nea Nikomedia in Greece in the white-on-red painted motifs such as triangles, sinuous and zigzag lines, some shapes of the pottery, as well as Impresso decoration, and with Thessaly (Presesklo and the beginning of Sesklo) in the white-on-red painted ware, similar to that of the proto-Sesklo phase, the typology of several dishes, and also with Hoça Çesme III in the white-on-red painted pottery with advanced ornamental features, Impresso pottery and incision motifs. On the other hand, white-on-red painted pottery also links Podgorie Ia-b with Kovaçevo, Asaği Pinar, Haçilar etc.

The polychrome pottery distinguishes Podgorie IVashtëmi from other similar cultures, placing this group chronologically at a later developmental stage of the Early Neolithic. Actually, the earliest stages of 
this cultural group are not known in Albania. On the other hand, its analogies and similarities, mentioned above, suggest that this culture could be considered as deriving from other Early Neolithic cultural groups of the AnatolianBalkan regions. It seems that the Podgorie I culture represents the third wave of Neolithisation in Albania, which arrived here by the Anatolian-Balkan route according to its cultural similarities to other neighbouring Early Neolithic cultures in Thessaly, Aegean Macedonia, Thrace and North Western Anatolia. This model of the spread of the 'Neolithic package' is included in so-called 'folk migration' as described by Zvelebil (2001.2), which stands for the movement of a population from region $\mathrm{A}$ to region $\mathrm{B}$, and the replacement of the old local populations, which also produces genetic/cultural changes at the same time. It appears that only during this phase were farming communities fully established in Albania.

During this phase (II1) we can see the extension of Neolithic groups into the deep hinterlands of Central and Eastern Albania. A strong Adriatic impulse moves from the southwest (e.g., from
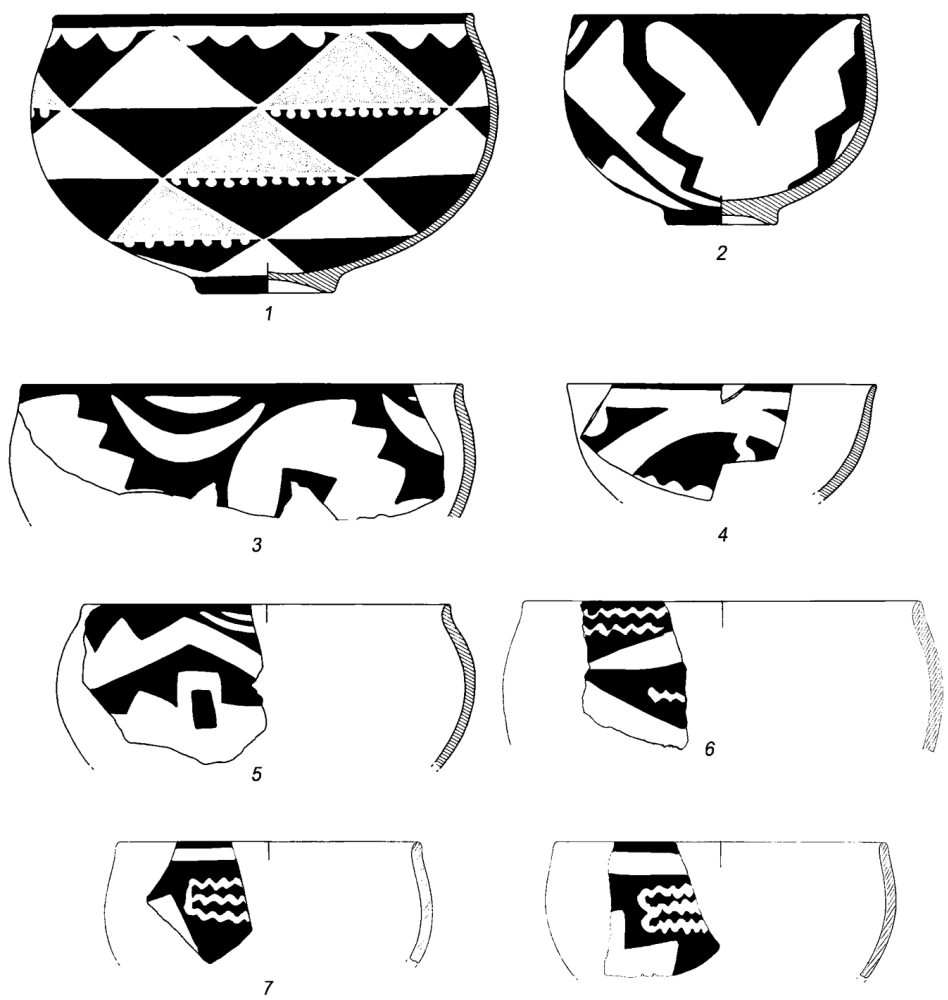

8
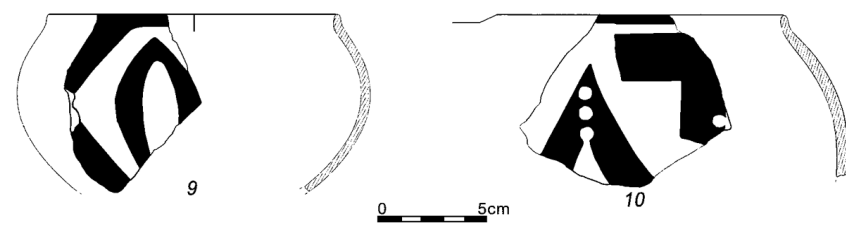

Pl. 5. White-on-red painted pottery from Podgorie Ia.

Konispol) to the east, establishing new sites of later chronological phases, such as the settlement caves at Blaz and Nezir (Mat), as well as the settlement cave at Katundas (Berat).

The Blaz cave settlement was excavated by Frano Prendi and Zhaneta Andrea from 1978 to 1979 (Prendi, Andrea 1981.19-21). Its second layer is characterised by coarse pottery, with grey, black or brown burnished exterior and especially Impresso pottery, which predominates. Impressions are the most common technique of pottery decoration. At Blaz II, three types of Adriatic pottery were represented, according to a classification carried out by Johannes Müller (1991.325-326). Type A Impresso predominates and covers the entire surface of vessels. In Dalmatia, this type of decoration has been dated to between 6100-5800 BC (Müller 1991.327). Cardium impresso is quite rare; only four sherds have been collected. Cardium impresso, including type B Adriatic Impresso, is dated to $5800-5600 \mathrm{BC}$ (Müller 1991.327). Only one example of type C Impresso, known as tremolo, with a wave motif, was found at Blaz II. In the Eastern Adriatic, this is dated to 5650-5600 BC (Müller 1991.327).

Barbotine pottery (5-6\%) has an ochre or reddish colour. Barbotine was applied in organised lines. This pottery does change the Adriatic character of the site, but shows the influence of the Starčevo IIb culture in the southwest. In this layer, a small cultic altar, painted dark brown, belonging to the Starčevo IIb culture, was found next to a rhyton fragment belonging to the Adriatic complex. A similar culture has been discovered at the Nezir cave settlement near Blaz. The Blaz II phase is almost contemporaneous with Zelena Pečina III-Obre I ( $2^{\text {nd }}$ phase) -Starčevo IIb, as well as Adriatic I (Impresso-cardium II).

Katundas (Berat) was excavated by Muzafer Korkuti in 1986 (Korkuti 1995a; 1995b.84). The Early Neolithic culture is characterised by Impresso pottery quite similar to Blaz II, barbotine ware, and semicoarse pottery in reddish colour. Only one fragment of a white-on-red painted vessel of Podgorie Ia style 
was found. This is important in chronological terms. Impresso pottery is the main characteristic of Katundas I, which marks the eastern border of the continental areas in which Adriatic elements had arrived.

On the other hand, during the phase (III1) in the north-eastern part of Albania, we can follow an Anatolian-Balkan wave from Starčvo IIb culture which reached all the way to Burim I (Dibër) during its earliest southerly extension (III1) and to Kolsh I (Kukës) during its greatest extension towards the southern and south-eastern Balkans (III2). The earlier Burim I phase is near the end of Starčevo I and the beginning of Starčevo IIa, the same as Anzabegovo-Vršnik Ib and Presesklo, while the older Kolsh I phase is equal to Starčevo IIb-Rudnik III-Anzabegovo-Vršnik III-Galabnik III and Sesklo (Fig. 3). The Early Neolithic cultures developed in close relation with neighbouring cultures, which was reflected by the interaction of a number of cultural elements of one group with another. This can be explained by the direct influence or movement of groups of people from one region to another.

According to the absolute chronology of Early Neolithic culture in Albania, only two Early Neolithic sites have produced radiocarbon dates so far, as follows:

- the beginnings of Konispol IIIa; a layer with Impresso pottery finds that yielded domestic animal bones (sheep and goat horns) (trench IX/20), dated to 6030-5710 and 6170-5800 calBC (Forenbaher, Miracle 2006.95, Pl. 3);

- the end of Konsipol IIIa, a layer which contained Impresso ware (trench IX/18), dated to 58405450 and 6000-5550 calBC (Forenbaher, Miracle 2006.95, Pl. 3).

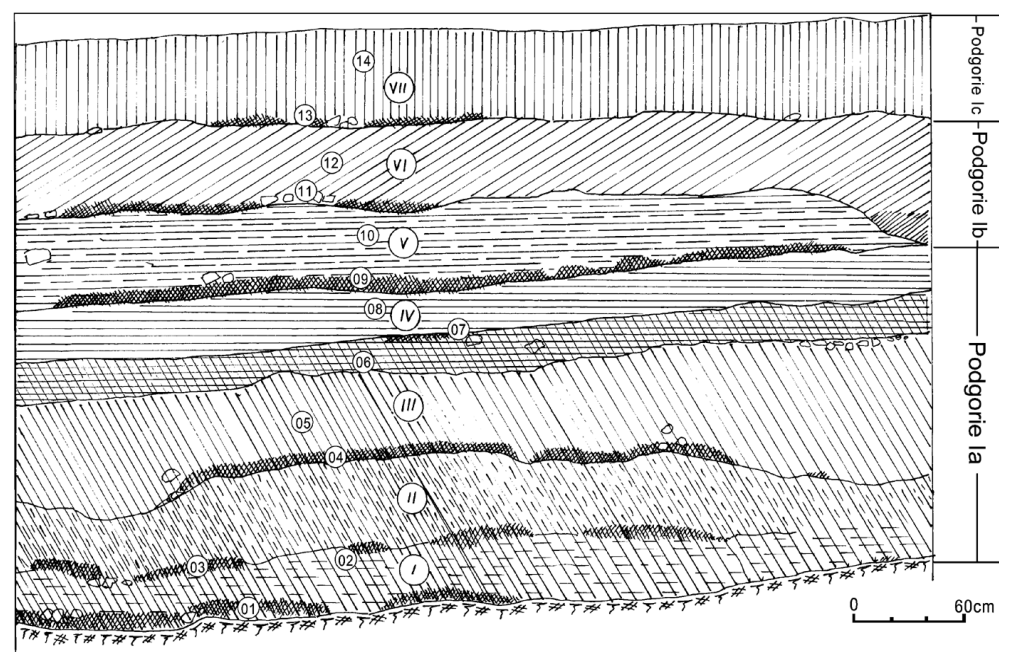

Fig. 9. Podgorie I profile.
According to the relative chronology, the three phases of Neolithisation in Albania produce the following picture:

I. Vlusha IIa = Škarin Samograd I - Sidar C base proto-Sesklo (partly Früh-Keramikum phase);

II. Konispol IIIa = Sidar C Top - Škarin Samograd II;

III. Podgorie I = Anzabegovo-Vršnik I (mainly phase Ic) - Veluška-Porodin I-II - Starčevo II - Nea Nikomedia - Presesklo (Magulica phase) and the beginning of the Early Sesklo-Cavdar phase.

\section{Conclusions}

It is necessary to summarise briefly the archaeological evidence about the three essential points of the Neolithisation of Albania discussed above. The present state of knowledge of this period allows for several conclusions to be drawn about the chronological, cultural and genetic aspects, despite the hypothetical nature of some of them, which could change with further investigation.

Thus far, no evidence has been found of the presence of a PPN horizon in Albania. The Blaz I phase, which lacks pottery, and is stratigraphically positioned after a hiatus below the Early Neolithic layer Blaz II, which contained Impresso pottery, cannot be securely associated with a proto-Neolithic phase with forms of productive economy; on the contrary, it pertains to the Epipalaeolithic period. Also, the attempt to consider the proto-Neolithic layer 13 in sector A12 at Sovjan (Korça basin) as the Epipaleolithic is based on the absence of pottery (Lera et al. 2007-2008.45). However, a Neolithic period without pottery has not been observed on the Eastern Adriatic coast of Dalmatia, where all the Early Neolithic settlements have produced pottery (Batović 1972.18; Benac 1971.336).

According to the archaeological research in Albania, we can refer to three different models of the Neolithisation process:

(1) The earliest appearance of Early Neolithic culture in Albania is related to the settlement at Vlusha (phase IIa). This culture is characterised by dark grey monochrome pottery, and by flint microliths of a Mesolithic tradition. In this early phase of its development, Impresso pottery does not appear at Vlusha IIa, which ap- 
peared in the second phase of the development of the Early Neolithic period, Vlusha II $b$. This stratigraphy is similar to that at Sidar on Corfu and Škarin Samograd in Dalmatia, where similar monochrome pottery layers were covered by an Impresso pottery layer in the Adriatic style (Müller 1988.259; Sordinas 1969. 401). This suggests that, on the territory of Albania, as in continental Greece, Impresso ware must not be considered the earliest type of Neolithic pottery. This is also supported by other sites with Impresso pottery finds discovered in Albania, which without exception date to a later stage of the Early Neolithic than that of Vlusha's monochrome ware. The particularities of the latter attest to its local evolution, but there is no evidence to support an autochthonous origin of the technology required to produce this pottery. On the other hand, if we were to refer to a possible affinity between the pottery of Vlusha IIa and the earliest monochrome pottery of Anatolia (Haçilar IX, Barçin Höyük; Gerritsen et al. 2013. 57, 70, Fig. 17-18), Thessaly (Frühkeramikum; Milojčić 1959.5,

Pl. 5) and Greece in general (Achilleon I and Sesklo I; Todorova 2003.264; and the earliest phase of Elatea; Sordinas 1969.406), Southwest Bulgaria (Krainici; Stefanova 1996.16- 17, Tab. I,1-4; Todorova 2003.264) and Northeast Bulgaria (Kuprivec, Pomishtica, Poljanica plato; Stefanova 1996.17), or the Central Balkans (Divostin; Krauß 2011.10), the possibility of the south-eastern origin of its technology tradition being in Anatolia and the Southeast Balkans moving north-west towards the Adriatic through demic diffusion and chaining transmission must not be excluded. Therefore, we believe that Vlusha IIa could be considered as representative of the first and earliest Anatolian influences in Albania, where indigenous populations with Mesolithic traditions have been present. With regard to the dynamics of the Neolithisation process of this settlement, this phenomenon would attest to the arrival in Vlusha of small groups of migratory farmers who brought the technology of pottery production and were influential in the acculturation of the indigenous Mesolithic population. Given the importance of the Mesolithic lithic tool industry at Vlusha IIa, it is possible to con-
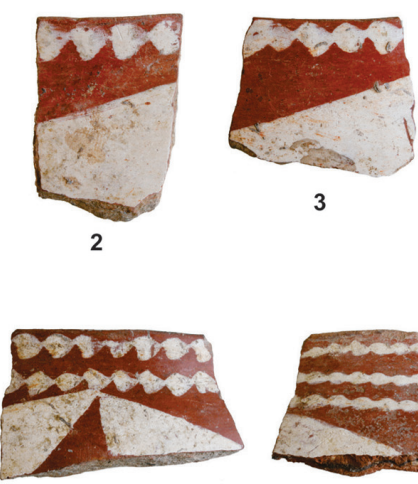

6
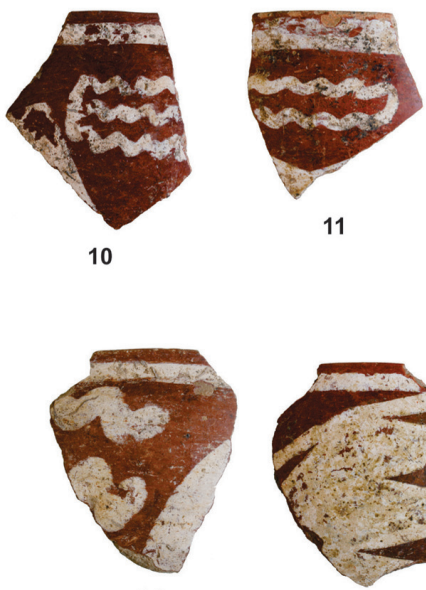

14
3

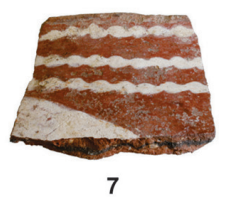

11

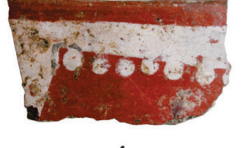

4

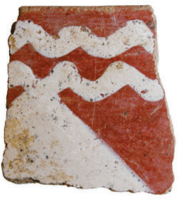

8

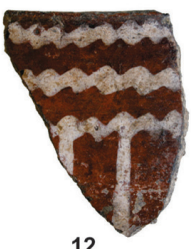

16

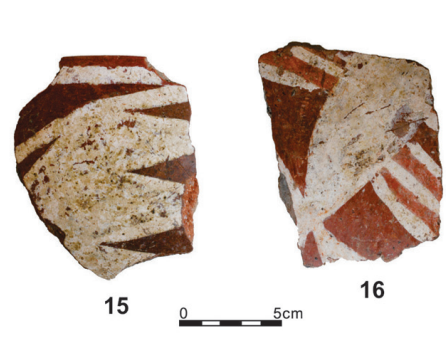

$$
14
$$

white-on-red painted pottery from Podgorie Ia.

clude that a hybrid process of the Neolithisation of Mesolithic peoples occurred at this site, which formed its culture through the co-existence of the indigenous and migratory populations which were associated with the assimilation and integration processes. In this context, Vlusha IIa would be included in the so-called 'leap-frog' model of colonisation (Zvelebil 2001.2). However, the transition process from the Mesolithic to the Early Neolithic, for example, from Mesolithic hunters to Early Neolithic herders and farmers at Vlusha IIa, is far from completely understood. There is a lack of evidence of whether the bearers of the Early Neolithic culture at Vlusha IIa learned the Neolithic way of life, which is why we believe that this settlement would have been used only seasonally. However, whatever the case may be, this remains an aspect which requires further investigation.

(2) The second phase of Neolithisation in Albania refers to the Konispol III phase, where we find the model of an indigenous settlement that developed directly from the Mesolithic, supporting the indigenous 


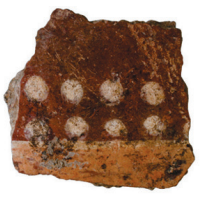

1
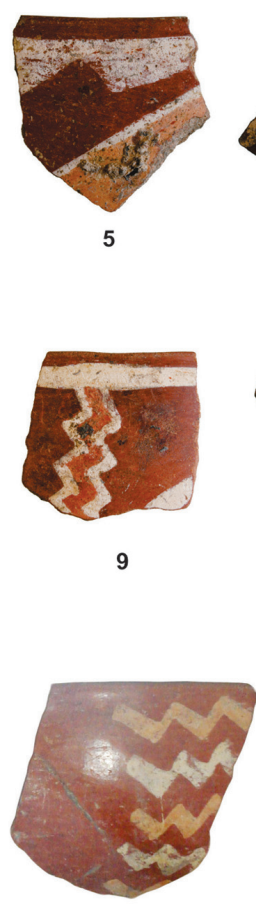

13

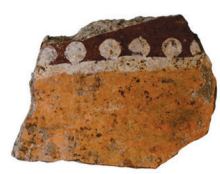

2

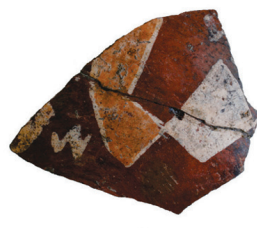

6

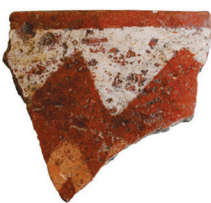

10

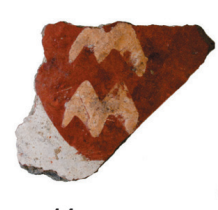

14
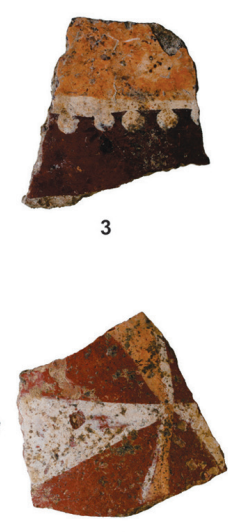

7

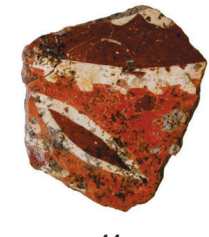

11

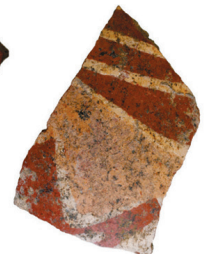

15

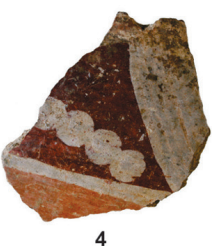

4

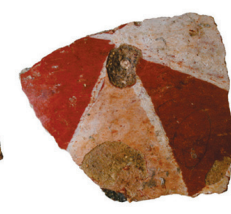

8
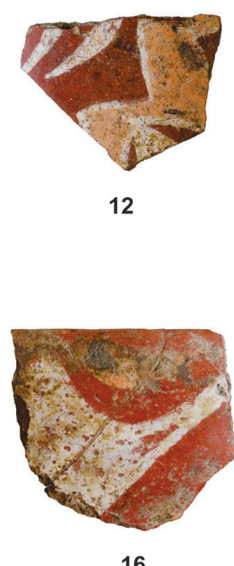

Pl. 7. Polycrome pottery from Podgorie Ia.

scenario. This is supported by the stratigraphic sequence at Konispoil, where the Early Neolithic layer with Impresso pottery of Konispol IIIa was deposited immediately, with no hiatus, above the Mesolithic layer of Konispol II. Konispol IIIa is contemporaneous with the Eastern Adriatic cultures of Sidar C Top, Škarin Samograd II, Crvena Stijena III, Zelena Pečina III, and Smilčič I. It was the Impresso ware which helped us to classify Konispol IIIa as the earliest representative of Adriatic influences in Albania, originating from the Eastern Mediterranean. We believe that the Impresso pottery at Konispol was acquired by cultural diffusion and acculturation processes from its closest neighbour, Sidar C Top on Corfu Island, only $35 \mathrm{~km}$ away, where this kind of pottery was ${ }^{14} \mathrm{C}$ dated to $6410-5990$ calBC (Müller 1991. 356). This date is earlier than the date for the Impresso pottery from Konispol IIIa phase, which is dated to 6170-5800 and 6000-5550 calBC (Korkuti et al. 1996.197; Korkuti 2003.221; Forenbaher, Miracle 2006.95, Tab. 3). In conclusion, we can say that Konispol IIIa would be included in the so-called 'regional contact' category (Zvelebil 2001.2), which entails trade and exchange relations with neighbouring communities, including the exchange of ideas and innovations. The second wave of Neolithisation seems to have taken an alternative route via the Aegean and Ionian Seas to the coast of the Ionian Sea, with first farmers arriving from the Eastern Mediterranean region.

3 The third phase of Neolithisation in Albania refers to the second Anatolian wave, characterised by monochrome red slipped ware, and red-onwhite painted pottery, represented by the cultural group of Podgorie IVashtëmi, while polychrome pottery was found only at the Podgorie I site. This quite advanced Early Neolithic ware was not preceeded in the Korça basin by an earlier development phase. Meanwhile, earlier phases of monochrome red slipped ware and red-on-white painted monochrome have been discovered in Western Anatolia (Erdogu 2005.97), Eastern Thrace (Hoça Çeşme and Aşaği Pinar; Özdoğan 2003.351; Perlès 2003; 2005.286), Aegean Macedonia (Nea Nikomedia), Eastern Macedonia (Anzabegovo-Vršnik I), Pelagonia (Veluška-tumba I) etc. These analogies lead us to the conclusion that the bearers of this cultural wave seem to have travelled along the Anatolian-Balkan route. This migration towards Southeast Albania included a third model of Neolithisation, so-called "folk migration" as described by Zvelebil (2001.2).

During this advanced Early Neolithic phase in the Korça basin, ritual secondary burials were carried out, as well as the differentiation of grave goods contained in them, which means there were socioeconomic inequalities. Similar cases have been reported in Nea Nikomedia in Aegean Macedonia (Rodden 1962.286, Tab. XLII; Theocharis 1981.Fig. 20; Perlès 2001.265, Fig. 12, 3; Sèferiedés 1995.89), in Mavropigi-Filosari in Western Macedonia (Karamitrou-Mentessidi et al. 2013.5, Fig. 7; Papathanasiou, Richards 2011.257, Fig. 7), dated to 6300-6000 calBC (Papathanasiou, Richards 2011.257), in Western Thessaly (Prodrom; Stratouli et al. 2010.96), Turkish Thrace (Hoca Çeşme; Sèfêriedés 1995.89), and in Aegean Anatolia (Burçin Höyük; Roodenberg et al. 2013.1-10, Fig. 2-4) etc. 
On the other hand, based on some clay biconoids (Renfrew 2003.413), known as sling-stones or sling shots, discovered at Podgori-Vashtëmi group, as well as on the other Early Neolithic cultural groups in Pelagonia (Simoska, Sanev 1975.47, Pl. II, 7; Naumov et al. 2009.Pl. 72, 7; Kitanovski et al. 1987.14, Pl. III, 2), Thessaly (Sesklo; Wace, Thomson 1912.Fig. 62), North-East Greece (Sitagroi I-II; Renfrew 2003. 413-414, Pl. 10), Aegean Macedonia (Nea Nikomedia), Anatolia (Çukuriçi Höyük; Barçin Höyük - Gerritsen et al. 2013.88, Fig. 22, 2; Uluçak Vb - Ciilingiroglu 2013.71, Fig. 4, c) etc., we believe that war and conflicts appeared in this phase of the Early Neolithic. According to the dominant opinion, such biconoids are Early Neolithic weapons (Rodden 1962. 285; Korkuti 1982.113; Séfériadés 1995.90). The appearance of conflicts and war at the end of the Early Neolithic would also be supported by the earliest prehistoric fortification, documented at Hoça Çesme IV (Özdoğan 1998.439, Fig. 3.a-b; 2003. 340), as well as the ramparts reinforced with palisade that emerged at Aşaği Pinar in Southeast Thrace (Özdoğan 2003.342). This new cultural change leads us to the conclusion that during this period, the real
Neolithic way of life had become established in the Korça basin and other regions of Albania; it was only during this phase that farmers really become completely Neolithicised in Albania.

The above picture, and especially the cultural similarities of Podgorie I to other neighbouring Early Neolithic cultures in Thessaly, Aegean Macedonia, Thrace and North Western Anatolia, lead us to the conclusion that the first and the third wave of Neolithisation may have been connected with the Anatolian-Balkan route.

The author thanks Prof. Mihael Budja (Ljubljana) for his invitation to take part in the 20 th Neolithic Seminar in Ljubljana to present a paper about the Neolithisation process in Albania. I would also like to thank Prof. Eszter Bànffy (Frankfurt am Main) for her useful discussion about the subject of this paper, as well as Dr. Christoph Rummel (Frankfurt am Main) for the correction of the translation of this paper.

\section{References}

Bánffy E. 2005. Mesolithic-Neolithic contacts as reflected in ritual finds. Documenta Praehistorica 32: 73-86.

Batović Š. 1972. Problemi neolitika na istočnoj Jadranskoj obali. IX. Kongres Arheologa Jugoslavije. Materijali XII: $17-24$.

Benac A. 1971. Quelques aspects de la néolithisation dans les Balkans du nord-ouest. Premieres communautés paysannes en medierranée occidentale: 335-341.

Brami M., Heyd V. 2011. The origins of Europe's first farmers: The role of Hacilar and Western Anatolia, fifty years on. Praehistorische Zeitschrift 86(2): 165-206.

Budja M. 1993. Neolithisation of Europe. The Slovene Aspect. Poročilo o raziskovanju paleolitika, neolitika in eneolitika v Sloveniji 21: 179-193.

1999. The transition to farming in Mediterranean European indigenous response. Documenta Praehistorica 26: $119-141$.

2001. The transition to farming in Southeast Europe: perspectives from pottery. Documenta Praehistorica 28: $27-47$.
Çilingiroğlu C.. 2005. The concept of "Neolithic package": considering its meaning and applicability. Documenta Praehistorica 32: 1-14.

Dörpfeld W. 1927. Alt Ithaka. Ein Beitrag zur HomerFrage. Gräfelfing. München.

Erdogu B. 2005. Visualizing Neolithic landscape: Archaeological Theory in the Aegean Islands. In C. Lichter (ed.), How Did Farming Reach Europe. Anatolian-European Relations from the Second Half of the $7^{\text {th }}$ through the First Half of the $6^{\text {th }}$ Millennium calBC. Proceedings of the International Workshop Istanbul, 20-22May 2004. BYZAS 2. Veroffentlichungen des Deutschen Archaologischen Instituts, 59-74. Yayinlari. Istanbul: 95-105.

Forenbaher S., Miracle P. S. 2006. The spread of farming in the Eastern Adriatic. Documenta Praehistorica 33: 89100.

Gerritsen F. A., Özbal R. and Thissen L. C. 2013. The earliest Neolithic Levels at Barcin Höyük, Northwestern Turkey. Anatolica XXXIX: 53-92.

Karamitrou-Mentessidi G., Efstratiou N., Kozłowski J. K., Kaczanowska M., Maniatis Y., Curci A., Michalopoulou S., 
Papathanasiou A. and Valamoti S. M. 2013. New evidence on the beginning of farming in Greece: the Early Neolithic settlement of Mavropigi in western Macedonia (Greece). Antiquity 87(336): 3-18.

Kitanovski B., Simoska D. and Todorović J. 1987. Radin Dol - Neolitska Naselba kaj Prilep. Macedoniae Acta Archaeologica 7-8: 7-29.

Korkuti M. 1982. Vashtëmia-një vendbanim i neolitit të hershëm. Iliria XII: 91-118.

1995a. Paleoliti në Shqipëri. Iliria XXV: 5-15.

1995b. Neolithikum und Chalkolithikum in Albanien. Internationale Interakademische Kommission für die Erforschung der Vorgeschichte des Balkans: Monographien. IV, Seite(n) 281; Tafeln I-LXXXII; Tafeln 1-121. Philipp von Zabern. Mainz.

2003. Researches and Studies of Prehistory in Albania. In D. V. Grammenos (ed.), Recent Research in the Prehistory of the Balkans. Publications of the Archaeological Institute of Northern Greece. N. 3. Archaeological Institute of Northern Greece. Thessaloniki: 205-255.

Korkuti M., Petrusso K., Bejko L., Harrold F., Ellwood B., Hansen J., Russell N. and Bottema S. 1996. Shpella e Konispolit (Konsipol Cave, Albania), 1992-1994. Iliria XXVI: 183-224.

Krauß R. 2011. On the "Monochrome" Neolithic in Southeast Europe. In R. Krauß (ed.), Beginnings - New Research in the Appearance of the Neolithic between Northwest Anatolia and the Carpathian Basin. Papers of the International Workshop $8^{\text {th-9th }}$ April 2009, Istanbul. Menschen - Kulturen - Traditionen. Forschungscluster 1. Verlag Marie Leidorf GmbH. Rahden/Westf.: 109121.

Lera P., Touchais G. and Oberweiler C. 2007-2008. Ndihmesa e gërmimeve të Sovjanit për kronologjinë absolute të prehistorisë shqiptare. Iliria XXXIII: 39-50.

Milojčić V. 1959. Ergebnisse der deutschen Ausgraben in Thessalien (1953-1958). Jahrbuch des Römisch-Germanischen Zentralmuseums in Mains 6: 1-56.

Müller J. 1988. Škarin Samograd - eine Früheneolithische Station mit monochromer Ware und Impresso Keramik an der Ostadria. Archäologisches Korrespondenzblatt 18: 219-235.

1991. Die ostadriatische Impresso-Kultur: Zeitliche Gliederung und kulturelle Einbindung. Germania 69(2): 311-358.
Naumov G., Fidanovski L., Tolevski I. and Ivkovska A. 2009. Neolitskite Zaednici vo Republika Makedonija. Dante. Skopje.

Nikolova L. 1998. Neolithic sequence: the upper Stryma valley in western Thrace (with an appendix: radiocarbon dating of the Balkan Neolithic). Documenta Praehistorica 25: 99-131.

Oross K., Banffy. E. 2009. Three successive waves of Neolithisation: LBK development in Transdanubia. Documenta Praehistorica 36: 175-189.

Özdoğan M. 1995. Neolithization of Europe: A view from Anatolia. Poročilo o raziskovanju paleolitika, neolitika in eneolitika $v$ Sloveniji 22: 25-61.

1998. Hoca Çeşme: An Early Neolithic anatolian colony in Balkans? In. P. Anreiter, L. Bartosiewicz, E. Jerem and W. Meid (eds.), Man and the Animal World. In memoriam Şándor Bókónyi. Archaeolingua 8. Budapest: 435-451.

2003. The Prehistory of Northwestern Turkey. In D. V. Grammenos (ed.), Recent Research in the Prehistory of the Balkans. Publications of the Archaeological Institute of Northern Greece, no. 3. Archaeological Institute of Northern Greece. Thessaloniki: 329-370.

Papathanasiou A., Richards M. P. 2011. Anthropological remains from the early sites at Mavropigi, Xirolimni and Pontokomi of the Early Neolithic in Western Macedonia. The Archaeological Work in Upper Macedonia 1: 257275.

Perlès C. (ed.) 1990. Les industries lithiques taillées de Franchthi (Argolide, Grèce). Tome II: Les industries du Mèsolithique et Nèolithique initial. Excavations at Franchthi Cave, Greece. Indiana University Press. Bloomington/Indianapolis.

2001. The Early Neolithic in Greece. The first farming communities in Europe. Cambridge World Archaeology. Cambridge University Press. Cambridge.

2003. An alternate (and old-fashioned) view of Neolithisation in Greece. Documenta Praehistorica 30: 99113.

2005. From the Near East to Greece: Let's reverse the focus cultural elements that didn't transfer. In C. Lichter (ed.), How did farming reach Europe. AnatolianEuropean Relations from the Second Half of the $7^{\text {th }}$ through the First Half of the $6^{\text {th }}$ Millennium calBC. Proceedings of the International Workshop Istanbul, 20-22May 2004. BYZAS 2. Veroffentlichungen des Deu- 
tschen Archaologischen Instituts, 59-74. Yayinlari. Istanbul: 275-290.

Prendi F. 1982. The Prehistory of Albania. The Cambridge Ancient History III(I): 187-192.

1990. Le Neolithique ancien en Albanie. Germania 68 (2): 399-426.

Prendi F., Andrea A. 1981. Të dhëna të reja mbi neolitin në Shqipëri. Iliria XI: 15-40.

Renfrew C. 2003. Special Clay Objects: Cylinders, Stamp Seals, Counters, Biconoids and Spheres. In E. S. Elster, C. Renfrew (eds.), Prehistoric Sitagroi, Excavations in Northeast Greece, 1968-1970. Vol. 2. The Final Report. Monumenta Archaeologica 20. Cotsen Institute of Archaeology at UCLA. Los Angeles: 403-414.

Rodden R. J. 1962. Excavations at the Early Neolithic Site at Nea Nikomedia, Greek Macedonia (1961 season). Proceedings of the Prehistoric Society XXVIII: 267-288.

Roodenberg M. S. A., Gerritsen A. F. and Özbal R. 2013. Neolithic burials from Barcin Hoyuk: The 2007-2012 excavations seasons. Anatolica XXXIX: 1-19.

Schubert H. 2005. Everyone's Black Box-Where does the European ornamention come from. In C. Lichter (ed.), How did farming reach Europe. Anatolian-European Relations from the Second Half of the $7^{\text {th }}$ through the First Half of the $6^{\text {th }}$ Millennium calBC. Proceedings of the International Workshop Istanbul, 20-22May 2004. BYZAS 2. Veroffentlichungen des Deutschen Archaologischen Instituts, 59-74. Yayinlari. Istanbul: 239-253.

Sèfèriedés M. L. 1995. The Neolithic of Greek Macedonia: from Nea Nikomedia to Dikili Tash. Poročilo o raziskovanju paleolitika, neolitika in eneolitika $v$ Sloveniji 22. 83-105.

Simoska D., Sanev V. 1975. Neolitka Naselba Veluška Tumba kai Bitola. Macedoniae Acta Archaeologica 1: 25-88.
Sordinas A. 1969. Investigations of the prehistory of Corfu during 1964-1966. Balkan Studies 10(2): 402-427.

2003. The "Sidarian": maritime Mesolithic non-geometric microlithics in western Greece. In N. Galanidou, C. Perlès (eds.), The Greek Mesolithic. Problems and Perspectives. Monograph of the British School at Athens 10. London: 89-97.

Srejović D. 1974. The Odmut cave. A new face of the Mesoneolithique Culture of the Balkan peninsula. Archeologica Jugoslavica 15: 3-6.

Stefanova T. 1996. A comparative analysis of pottery from the "Monochrome Early Neolithic Horizon" and "Karanovo I Horizon" and the problems of the neolithization of Bulgaria. Poročilo o raziskovanju paleolitika, neolitika in eneolitika $v$ Sloveniji 23: 15-38.

Stratouli G., Triantaphyllou S., Bekiaris T. and Kastikaridis N. 2010. The manipulation of death: a burial area at the Neolithic Settlement of Avgi, NW Greece. Documenta Praehistorica 37: 95-104.

Theocharis D. R. 1981. Neolithikos Politismos. National Bank of Greece. Athens.

Todorova H. 2003. Prehistory of Bulgaria. In D. V. Grammenos (ed.), Recent Research in the Prehistory of the Balkans. Publications of the Archaeological Institute of Northern Greece. N. 3. Archaeological Institute of Northern Greece. Thessaloniki: 257-289.

Wace A. J., Thompson M. S. 1912. Prehistoric Thessaly. Cambridge University Press. Cambridge.

Zvelebil M. 1995. Neolithization in Eastern Europe: A view from the frontier. Poročilo o raziskovanju paleolitika, neolitika in eneolitika v Sloveniji 22: 107-151.

2001. The Agricultural Transition on the origins of Neolithic Society in Europe. Documenta Praehistorica 28: $1-26$. 